\title{
Biosystematics, genetics and upper temperature tolerance of Gigartina teedii (Rhodophyta) from the Atlantic and Mediterranean
}

\author{
M. D. Guiry ${ }^{1}$, G. Tripodi ${ }^{2}$ \& K. Lüning ${ }^{3}$ \\ ${ }^{1}$ Department of Botany, The National University of Ireland, University College; Galway, \\ Republic of Ireland \\ 2 Istituto di Botanica, Università di Messina; Via P. Castelli 2, I-98100 Messina, Italy \\ ${ }^{3}$ Biologische Anstalt Helgoland (Zentrale); Notkestr. 31, D-2000, Hamburg 52, FRG
}

\begin{abstract}
Plants of Gigartina teedii from the Mediterranean isolated into laboratory culture showed Polysiphonia-type life histories with consistent formation of dioecious gametangial plants, as previously reported for Atlantic isolates. Male and female plants from the Atlantic and Mediterranean were almost completely compatible in terms of cystocarp formation on female plants, and carpospores from positive crosses always formed plants that released viable tetraspores. Sex-linked inheritance of branching pattern was found in all strains, but showed varying degrees of expression. Female plants were more branched than male plants and it is suggested that this may be an adaptation for spermatial capture. G. teedii plants showed differences in morphology in culture that are considered to be genetically-based. Preliminary studies of tip elongation showed that Mediterranean strains may have up to three times the elongation rates of Atlantic strains at $15^{\circ} \mathrm{C}, 16: \overline{8} \mathrm{~h}$. Such genetic variation in fully-interbreeding strains suggests that populations of this species in the Atlantic and Mediterranean are genecodemic. All strains showed an upper temperature tolerance of $31{ }^{\circ} \mathrm{C}$ when tested at $1{ }^{\circ} \mathrm{C}$ intervals from $29-34^{\circ} \mathrm{C}$. An upper temperature tolerance of $31-32^{\circ} \mathrm{C}$ was found for the related species $G$. intermedia from Korea and Japan, but G. johnstonii from the Gulf of California showed an upper tolerance of $32-33^{\circ} \mathrm{C}$.
\end{abstract}

\section{INTRODUCTION}

The most commonly used unit in biogeography is the species. There is, however, no universally accepted species concept. For marine algae, the morphological species concept (Mayr, 1942) is the most widely used, species being distinguished on the basis of key characteristics; a seaweed species might be regarded, somewhat cynically by some, as what a competent taxonomist considers it to be. Darwin (1859) stated that the ". . . amount of difference necessary to give any two forms the rank of species cannot be defined"; this remains substantially true today and, despite all the advances of the 20th century, the majority of taxonomists are morphologists. The biological species concept (Mayr, 1942) has gained widespread, although not universal, approval among marine botanists. More recently, Mayr (1982) has defined the species as ". . a reproductive community of populations (reproductively isolated from others) that occupies a specific niche in nature". Although formulated with animal species in mind, the definition is also 
appropriate for plants (Russell, 1986) as it considers also ecological, geographical and genetic features in the concept of a species. Some difficulties have been found in relating the concept - in terms of reproductive isolation - to certain marine algae (Chapman, 1978). Rice \& Chapman (1985) have stated that the biological species concept of Mayr (1969) is inappropriate for Fucus because of the high incidence of hybrids amongst the species of this genus; Russell (1986) contended, however, that sexual isolation is a relative character of some use. In many red algae, isolation is difficult to assess because of monoeciousness and non-sexual life cycles. Relatively few studies of sexual compatibility have been carried out on Rhodophyta (cf. Mathieson et al., 1981 for a recent review), largely because of the extremely time-consuming isolation and maintenance of suitable cultures. Much of the infraspecific morphological variation in red algae has been ascribed to ecological causes, be they local or geographical; the possibility that this variation may, in part, be genetically based should also be considered.

Gigartina teedii (Roth) Lamouroux (Gigartinales, Gigartinaceae) is a relatively uncommon, perennial alga of the intertidal and shallow subtidal in the Atlantic and Mediterranean. In the eastern Atlantic, it is found from the mid-west coast of Ireland (Guiry \& Maggs, 1985) south to South Africa but is less widespread in the western Atlantic (see Guiry, 1984). In the Mediterranean, G. teedii has not been found in Spain (Gallardo et al., 1985), France (Feldmann, 1941), Corsica .(Boudouresque \& Perret, 1977), Tunisia (Meñez \& Mathieson, 1981), Lybia (Nizamuddin et al., 1979) and thus seems to be absent from the western reaches of the Mediterranean. In Italy, it has been reported from Naples, Sicily and the Adriatic Sea (Giaccone, 1969, 1978; Giaccone et al., 1985). In the eastern Mediterranean it has been found in Macedonia (Haritonidis \& Tsekos, 1975), Attica and Crete (Politis, 1936).

In the course of studies of the life history, photoperiodic responses and distribution of G. teedii (Guiry, 1984; Guiry \& Maggs, 1985), sufficient isolates from the Atlantic and Mediterranean have been accumulated to allow an account of their form variation, growth, genetics and sexual compatibility to be presented.

\section{MATERIALS AND METHODS}

\section{Isolation and maintenance of strains}

Cultures of Gigartina teedii were isolated from plants collected at the localities listed in Table 1. These were started from spores or from apical portions of the thalli isolated according to the methods given in West \& Guiry (1982), Guiry \& West (1983), Guiry (1984) and Guiry \& Maggs (1985). A modification of Von Stosch's Enriched Seawater (VSES; Guiry \& Cunningham, 1984) was used at $50 \%$ strength for long-term cultivation and for crossability studies. Cultures required medium replenishment every $2-4$ weeks at $15^{\circ} \mathrm{C}$, $16: \overline{8} \mathrm{~h}$ (light:dark), $30 \mu \mathrm{mol}$ photons $\mathrm{m}^{-2} \mathrm{~s}^{-1}$, depending on the size of the plants. For stock cultures, four detached plants $20-45 \mathrm{~mm}$ long were maintained for the different reproductive states of each strain and tips $10-15 \mathrm{~mm}$ in length were excised when cultures were being changed. The maximum length of one marked plant in each culture was measured after excision and again after 2-3 weeks in culture. These growth measurements were converted to a tip elongation rate (TE) using the formula TE (in $\mathrm{mm}$ $\left.\operatorname{day}^{-1}\right)=\left(l_{2}-l_{1}\right) / T$ where $l_{1}=$ initial length, $l_{2}=$ final length and $T=$ number of days. This 
Table 1. Origins of isolates of Gigartina teedii.

\begin{tabular}{|rlll|}
\hline $\begin{array}{l}\text { Culture number } \\
\text { (MDG) }\end{array}$ & Country & Locality & $\begin{array}{l}\text { Date of } \\
\text { collection }\end{array}$ \\
\hline 503 & Ireland & New Quay & Sept. 1984 \\
62 & England & River Yealm & Sept. 1976 \\
388 & France & Rade de Brest & Sept. 1981 \\
464 & Italy & Sicily & April 1983 \\
489 & Greece & Thessaloniki & Nov. 1983 \\
$366^{*}$ & Brazil & São Paulo & Unknown \\
$367^{\circ}$ & Brazil & São Paulo & Unknown \\
Obtained from the culture collection of & J. A. West, Department of Botany, University of \\
California at Berkeley (culture no. 2205) & & \\
\hline
\end{tabular}

formula was used in preference to logarithmic expressions as preliminary studies indicated that tip elongation is linear (see Kain, 1987).

\section{Crossability studies}

Two separate experiments were carried out to assess crossability between strains of Gigartina teedii. The crosses shown in Fig. 12 were carried out at $15^{\circ} \mathrm{C}, 16: \overline{8} \mathrm{~h}, 30-35$ $\mu \mathrm{mol}$ photons $\mathrm{m}^{-2} \mathrm{~s}^{-1}$ and were all initiated at the same time. Two female plants forming carpogonial branćhes (as determined under a binocular microscope where the supporting cells are easily seen as brilliant points; cf. West \& Guiry, 1982) and one male plant forming and releasing spermatia were placed in $250-\mathrm{ml}$ culturing dishes. Plants were not agitated. In positive crosses, carpospores were released 5-7 weeks after the crosses were initiated. The crosses shown in Figure 13 were carried out in a similar manner at $15^{\circ} \mathrm{C}$, $16: \overline{8} \mathrm{~h}, 4-5 \mu \mathrm{mol}$ photons $\mathrm{m}^{-2} \mathrm{~s}^{-1}$.

\section{Upper temperature tolerance studies}

Unialgal cultures of the isolates listed in Table 3 were sent to Lüning's laboratory in Hamburg and propagated for several months in crystallizing dishes at $15^{\circ} \mathrm{C}, 16: \overline{8} \mathrm{~h}, 30$ $\mu \mathrm{mol}$ photons $\mathrm{m}^{-2} \mathrm{~s}^{-1}$. Portions of thalli $10-20 \mathrm{~mm}$ long with at least one dichotomy were used in the temperature experiments.

Upper temperature tolerance experiments were carried out at $1^{\circ} \mathrm{C}$ intervals from $29-34^{\circ} \mathrm{C}$ (Table 3 ) for two weeks using the incubation and automatic seawater replacement system described by Lüning et al. (1987, present volume). Plants were evaluated after 4 and 8 weeks incubation at $15^{\circ} \mathrm{C}, 16: \overline{8} \mathrm{~h}, 10 \mu \mathrm{mol} \mathrm{m} \mathrm{m}^{-2} \mathrm{~s}^{-1}$ in half-strength VSES. Plants were assessed for survival as described by Lüning et al. (1987). 


\section{RESULTS}

\section{Life history}

Only female plants were isolated vegetatively from a single field-collected female plant from Ireland (Guiry \& Maggs, 1985). All other strains (Table 1) had a Polysiphoniatype life history in culture with tetraspores giving rise exclusively to dioecious erect gametangial plants. Carposporophytes were formed only on female plants in the presence of male plants releasing spermatia ${ }_{i}$ isolated female plants remained sterile. Carpospores released from carposporophytes gave rise to erect plants that formed tetrasporangia. The sequence of phases was relatively rapid in cultures, and a complete cycle could be achieved in 8-12 months.

\section{Morphological differences between strains}

Considerable morphological differences between strains were observed in culture. The female Irish strain (Fig. 1) was crimson in colour, narrow, almost terete with many pinnate branches. The strains from England (Figs 2,3) and France were also crimson or brownish-red in colour, narrow and slightly more flattened than the Irish strain and had irregular or regular pinnate branching. Male plants tended to be slightly less branched than female plants. Female plants from France were very densely branched and their branches tended to recurve, resulting in a densely-compacted plant. Male plants of the mutant green Brazilian strain were olive-green in colour, almost terete, very narrow and much less branched in an irregularly pinnate manner (Fig. 4). Female plants of the wildtype and the recovered mutant green strains from Brazil were blackish-brown or green, flattened, narrow, and profusely regularly pinnately branched (Figs 5,6). Male wild-type plants recovered from the Brazilian strain were narrow, relatively sparsely branched, but tended to produce more pinnately-arranged branches than the mutant green strain. Plants from Italy and Greece (Figs 8-11) were brownish-red in colour under low irradiances (ca $3 \mu \mathrm{mol}$ photons $\mathrm{m}^{-2} \mathrm{~s}^{-1}$ ), but under higher irradiances (ca $30 \mu \mathrm{mol}$ photons $\mathrm{m}^{-2} \mathrm{~s}^{-1}$ ) tended to become yellowish-brown in colour, a phenomenon not observed in the Atlantic strains. At higher irradiances, the female strain from Greece (Fig. 11) became bright green in colour in the main axes and larger lateral branches, a phenomenon that persisted through several life history cycles and over a period of several years. In general, male and female plants of Gigartina teedii from the Mediterranean were broader and more irregularly branched than strains from the Atlantic.

\section{Growth differences between strains}

Plants shown in Figures 1-11 were photographed 4 weeks after two detached tips had been cut back to a maximum length of $10-12 \mathrm{~mm}$ and grown at $15 \pm 1^{\circ} \mathrm{C}, 16: \overline{8} \mathrm{~h}$, 22-25 $\mu \mathrm{mol}$ photons $\mathrm{m}^{-2} \mathrm{~s}^{-1}$. The difference in the rate of tip elongation between Mediterranean and Atlantic strains is strikingly obvious and branching rates are clearly lower in the Italian and Grecian strains. Rates of tip elongation measured over a two-year period are shown in Table 2. The Atlantic plants show tip elongation rates of $0.13-0.35$ $\mathrm{mm} \mathrm{d}^{-1}$, the lowest rates being found in the Brazilian female wild-type strain and the 

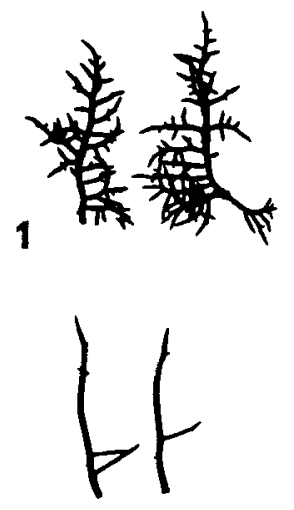

4
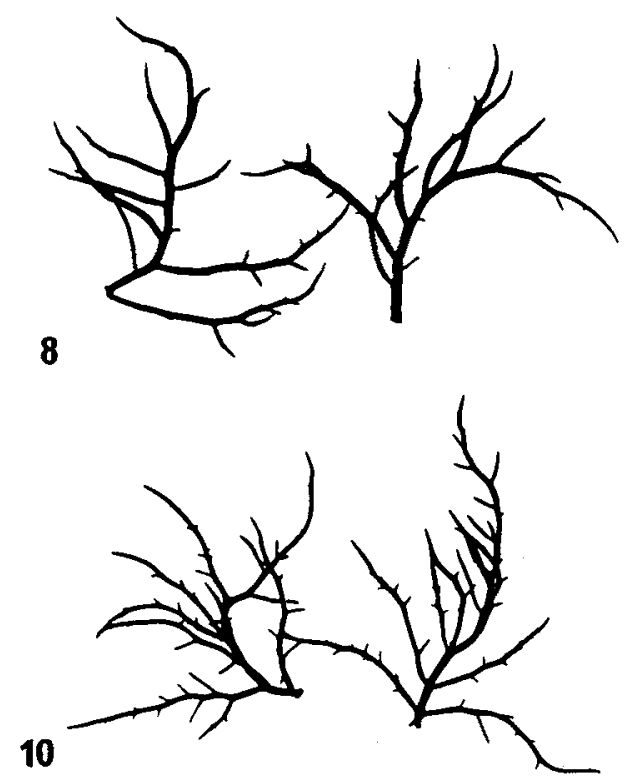

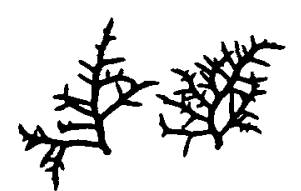

5

9

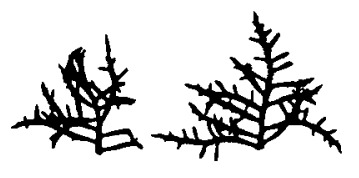

6

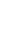

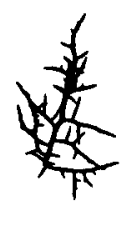

3
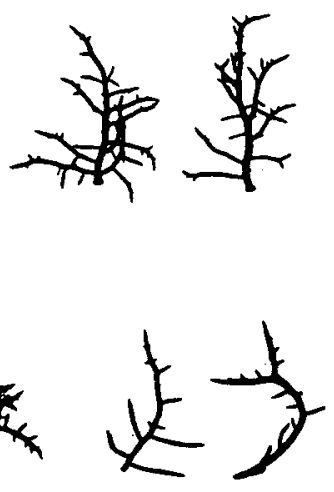

7

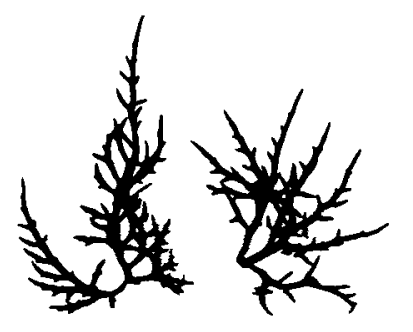

11

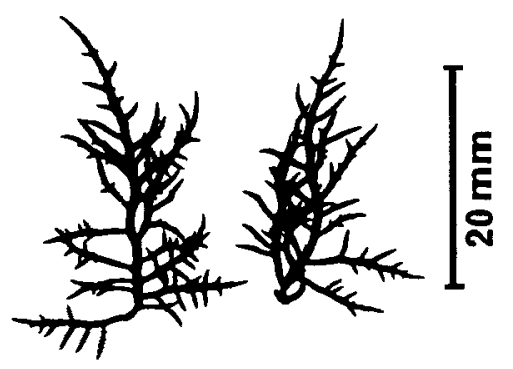

Figs 1-11. Excised tips of Gigartina teedii plants in culture. Tips 10-12 mm long were excised and photographed after four weeks in culture at $15^{\circ} \mathrm{C}, 16: \overline{8} \mathrm{~h}, 22-25 \mu \mathrm{mol}$ photons $\mathrm{m}^{-2} \mathrm{~s}^{-1}$. Scale in Fig. 11 applies to all plants. Fig. 1. Female wild-type plants from Ireland (503). Fig. 2. Male wild-type plants from England (62). Fig. 3. Female wild-type plants from England (62). Fig. 4. Male mutant green plants from Brazil (367). Fig. 5. Female wild-type plants from Brazil (366). Fig. 6. Fermale mutant green plants from Brazil (367). Fig. 7. Male wild-type plants from Brazil (366). Fig. 8. Male wild-type plants from Italy (464). Fig. 9. Female wild-type plants from Italy (464). Fig. 10. Male wildtype plants from Greece (489). Fig. 11. Female wild-type plants from Greece (489) 
Table 2. Tip elongation (in mm d $\mathrm{m}^{-1}$ ) of various isolates of Gigartina teedii in culture at $15^{\circ} \mathrm{C}, 16: \overline{8} \mathrm{~h}$. Measurements were made of single plants every 28-35 days over a two-year period. Collection data are given in Table 1. Except where stated, strains were wild-type

\begin{tabular}{|lcccc|}
\hline Strain & $\begin{array}{c}\text { Culture } \\
\text { number }\end{array}$ & Mean & $\begin{array}{c}\text { Standard } \\
\text { deviation }\end{array}$ & $\begin{array}{c}\text { Number of } \\
\text { measurements }\end{array}$ \\
\hline Ireland Female & 503 & 0.25 & 0.08 & 22 \\
England Male & 62 & 0.31 & 0.16 & 21 \\
England Female & 62 & 0.34 & 0.15 & 21 \\
France Male & 388 & 0.35 & 0.17 & 21 \\
France Female & 388 & 0.27 & 0.08 & 17 \\
Italy Male & 464 & 0.58 & 0.17 & 22 \\
Italy Female & 464 & 0.49 & 0.14 & 21 \\
Greece Male & 489 & 0.70 & 0.15 & 22 \\
Greece Female & 489 & 0.73 & 0.13 & 20 \\
Brazil Male (green) & 367 & 0.24 & 0.05 & 17 \\
Brazil Female (red) & 366 & 0.13 & 0.04 & 9 \\
Brazil Male (red) & 367 & 0.24 & 0.07 & 9 \\
Brazil Female (green) & 366 & 0.20 & 0.05 & 19 \\
\hline
\end{tabular}

highest in the English male and female strains. The Mediterranean plants showed tip elongation rates 2-3 times higher than the Atlantic plants with the Grecian isolates being significantly faster-growing than the Italian isolates. Differences in tip elongation rates were evident between male and female plants; generally the male isolates showed higher rates than the females. This was particularly pronounced in the Brazilian strains (Table 2).

\section{Crossability between strains}

In general, no difficulty was experienced in achieving fertilization between the strains from Ireland, France, Italy, Greece and Brazil at $15^{\circ} \mathrm{C}, 16: \overline{8} \mathrm{~h}, 30-35 \mu \mathrm{mol}$ photons $\mathrm{m}^{-2} \mathrm{~s}^{-1}$. However, there was a low incidence of fertilization in both the male and female strains from England (Fig. 12). The female strain only formed viable cystocarps when crossed to the Brazilian male. The English male strain only formed cystocarps when crossed to the Irish, French and Italian strains, but no cystocarps were formed in a selfcross or with the Brazilian or Grecian females and only the French and Italian crosses released carpospores. It had previously been noted that female plants of the English strain formed longer trichogynes under lower irradiances and it was decided to repeat all crosses at $15^{\circ} \mathrm{C}, 16: \overline{8} \mathrm{~h}, 4-5 \mu \mathrm{mol}$ photons $\mathrm{m}^{-2} \mathrm{~s}^{-1}$. A higher incidence of fertilization of female plants was obtained under these conditions (Fig. 13), but again, no release of carpospores was obtained from a self-cross of the English plants although a single poorlydeveloped cystocarp was formed. No cystocarps were formed on female plants of the French strain when crossed to male plants of the English strain on this occasion, even though cystocarps and spore releases were obtained for this cross in the first experiment (Fig. 12). Self-fertilization, however, was obtained in the Grecian plants, which had been unsuccessful in the earlier series.

In order to determine if any sterility barriers had occurred in progeny from these crosses, carpospores released during the first series of crosses (Fig. 12) were grown to 
Male

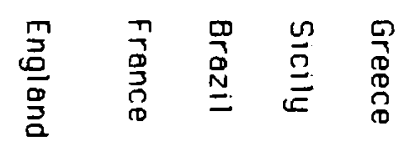

Male

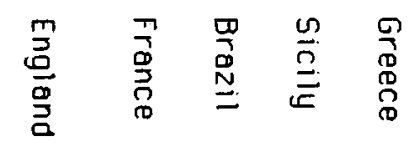

\begin{tabular}{l|c|c|c|c|c|}
\cline { 2 - 6 } Female & 62 & 388 & 367 & 464 & 489 \\
\hline Ireland 503 & 0 & $\bullet$ & $\bullet$ & $\bullet$ & $\bullet$ \\
\hline England 62 & - & 0 & $\bullet$ & - & - \\
\hline France 388 & $\bullet$ & $\bullet$ & $\bullet$ & $\bullet$ & $\bullet$ \\
\hline Brazil 366 & - & $\bullet$ & $\bullet$ & $\bullet$ & $\bullet$ \\
\hline Sicily 464 & $\bullet$ & $\bullet$ & $\bullet$ & $\bullet$ & $\bullet$ \\
\hline Greece 489 & - & $\bullet$ & $\bullet$ & $\bullet$ & 0 \\
\hline
\end{tabular}

\begin{tabular}{l|c|c|c|c|c|}
\cline { 2 - 6 } Female & 62 & 388 & 367 & 464 & 489 \\
\hline Ireland 503 & $\bullet$ & $\bullet$ & $\bullet$ & $\bullet$ & $\bullet$ \\
\hline England 62 & 0 & $\bullet$ & $\bullet$ & $\bullet$ & $\bullet$ \\
\hline France 388 & - & $\bullet$ & $\bullet$ & $\bullet$ & $\bullet$ \\
\hline Brazil 366 & $\bullet$ & $\bullet$ & $\bullet$ & $\bullet$ & $\bullet$ \\
\hline Sicily 464 & $\bullet$ & $\bullet$ & $\bullet$ & $\bullet$ & $\bullet$ \\
\hline Greece 489 & $\bullet$ & $\bullet$ & $\bullet$ & $\bullet$ & $\bullet$ \\
\hline
\end{tabular}

Fig. 12 (left). Results of attempted crosses of male and female plants of Gigartina teedii at $15^{\circ} \mathrm{C}, 16: \overline{8}$, 30-35 $\mu \mathrm{mol}$ photons $\mathrm{m}^{-2} \mathrm{~s}^{-1}$. Symbols: $-=$ no cystocarps formed; $0=$ cystocarps formed, but no

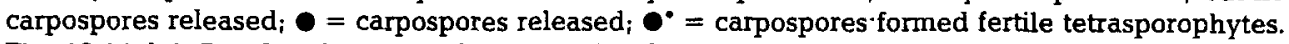
Fig. 13 (right). Results of attempted crosses of male and female plants of Gigartina teedii at $15^{\circ} \mathrm{C}$, $16: \overline{8} \mathrm{~h}, 4-5 \mu \mathrm{mol}$ photons $\mathrm{m}^{-2} \mathrm{~s}^{-1}$. Symbols: as above

reproductive maturity at $15^{\circ} \mathrm{C}, 16: \overline{8} \mathrm{~h}, 20-25 \mu \mathrm{mol}$ photons $\mathrm{m}^{-2} \mathrm{~s}^{-1}$. Tetrasporangia were formed on all the resulting plants in 6-8 months (Fig. 12) and tetraspores, with what appeared to be normal viability, were released.

\section{Genetics}

An olive-green mutant male strain form Brazil (Fig. 4) arose spontaneously in culture (Guiry, 1984). This strain was crossed to wild-type, blackish-brown female plants (Fig. 5), also from Brazil. Only wild-type tetrasporophytes were obtained, which were, however, lighter brown than the female strain. Tetraspores yielded blackish-brown and green plants in a 1:1 ratio. On maturity, four classes of plants were apparent: blackish-brown male plants, blackish-brown female plants, green male plants and green female plants. No deviation from this pattern was observed over a number of years and several life history cycles. Similar crosses with the other strains gave the same results and provided additional evidence that cross-fertilization was taking place.

A striking feature of both green and blackish-brown male plants was how different they were in morphology to green and blackish-brown female plants. Male plants of both colour variants (Figs 4,7 ) were irregularly and sparsely branched. Female plants of both colour variants, on the other hand, were regularly pinnately branched with many branches (Figs 5,6). Plants grown from tetraspores showed these branching patterns in a 1:1 ratio and the pattern was always sex-related. These branching patterns were reflected in tip elongation rates measured in isolates of colour variants (Table 2). Female isolates always showed lower tip elongation rates than males, regardless of colour. 
Sexual differences in branching pattern were most obvious in the Brazilian strain, but sexual dimorphism also occurred in other strains, particularly the French and Italian isolates in which male plants showed a lower incidence of branching and higher tip elongation rates (Table 2).

\section{Upper temperature tolerance}

Atlantic and Mediterranean strains of Gigartina teedii uniformly survived $31^{\circ} \mathrm{C}$ (Table 3). The uniform temperature tolerance exhibited by these strains does not only relate to geographical origin $;$ no differences between sexes was observed.

Strains of $G$. intermedia from Korea and Japan also showed a very similar upper tolerance temperature of $31-32^{\circ} \mathrm{C}$, but strains 405 (Korea) and 442 (Japan) survived $32^{\circ} \mathrm{C}$ whilst 483 and 484 (both from Japan) did not survive this temperature (Table 3). However, a male strain of $G$. johnstonii from Puerto Peñasco in the upper reaches of the Gulf of California (cf. West \& Guiry, 1982, for further details), survived a temperature of $33^{\circ} \mathrm{C}$ (Table 3).

Table 3. Gigartina spp. Upper temperature tolerance of geographical isolates. Duration of treatment was 2 weeks. Results were evaluated after a post-treatment of 4 or 8 weeks at $15^{\circ} \mathrm{C}, 16: \overline{8} \mathrm{~h}, 20 \mu \mathrm{mol}$ photons $\mathrm{m}^{-2} \mathrm{~s}^{-1}$. xxxx: whole thallus survived; $(\mathrm{xx})$ : regeneration from a few surviving cells;...- : whole thallus dead

\begin{tabular}{|c|c|c|c|c|c|c|c|c|}
\hline \multirow[t]{2}{*}{ Species } & \multirow[t]{2}{*}{ Strain } & \multirow{2}{*}{$\begin{array}{l}\text { Culture } \\
\text { number }\end{array}$} & \multicolumn{6}{|c|}{ Temperature over two weeks $\left({ }^{\circ} \mathrm{C}\right)$} \\
\hline & & & 29 & 30 & 31 & 32 & 33 & 34 \\
\hline \multirow[t]{15}{*}{ G. teedii } & \multirow[t]{2}{*}{ Ireland Female } & \multirow[t]{2}{*}{$503-2586$} & $\mathrm{xxxx}$ & $\mathbf{x x x x}$ & $x x x x$ & $\cdots$ & $\ldots$ & $\ldots$ \\
\hline & & & $x x x x$ & $\mathbf{x x x x}$ & $(x x)$ & $\cdots$ & $\cdots$ & $\cdots$ \\
\hline & \multirow[t]{2}{*}{ England Male } & \multirow[t]{2}{*}{$62-2570$} & $\mathbf{x x x x}$ & $\mathbf{x x x x}$ & $x x x x$ & $\cdots$ & $-\cdots$ & \\
\hline & & & $x x x x$ & $\mathrm{xxxx}$ & $x x x x$ & $\cdots$ & $\cdots$ & $\cdots$ \\
\hline & \multirow[t]{2}{*}{ England Female } & \multirow[t]{2}{*}{$62-2571$} & $\mathbf{x x x x}$ & $\mathbf{x x x x}$ & $\mathbf{x x x x}$ & $\cdots$ & $-\cdots$ & $\cdots$ \\
\hline & & & $\mathbf{x x x x}$ & $x x x x$ & $\mathbf{x x x x}$ & $\cdots$ & $\cdots$ & $\cdots$ \\
\hline & \multirow[t]{2}{*}{ France Male } & \multirow[t]{2}{*}{$388-2574$} & $x x x x$ & $\mathrm{xxxx}$ & $(x x)$ & $\cdots$ & $\ldots$ & $\ldots$ \\
\hline & & & xxoxx & $(\mathbf{x x})$ & $(x x)$ & $\cdots$ & $\ldots$ & $\cdots$ \\
\hline & \multirow[t]{2}{*}{ France Female } & \multirow[t]{2}{*}{$388-2575$} & $x x x x$ & $x x x x$ & $x \times x x$ & $\cdots$ & $\cdots$ & $\cdots$ \\
\hline & & & $\operatorname{xxcxx}$ & $\mathrm{xxxx}$ & $(x x)$ & $\cdots$ & $\ldots$ & $\cdots$ \\
\hline & \multirow[t]{2}{*}{ Italy Male } & \multirow[t]{2}{*}{$464-2579$} & $\operatorname{xxxx}$ & $\mathbf{x x x x}$ & $\mathbf{x x x x}$ & $\cdots$ & $\cdots$ & $\cdots$ \\
\hline & & & $x x x x$ & $\mathrm{xxxx}$ & $(\mathrm{xx})$ & $\cdots$ & $\cdots$ & $\cdots$ \\
\hline & Italy Female & $464-2580$ & $x x x x$ & $\mathbf{x x x x}$ & $(x x)$ & $\cdots$ & $\cdots$ & $\cdots$ \\
\hline & Greece Male & 489-2584 & $\mathbf{x x x x}$ & $\mathbf{x x x x}$ & $(x x)$ & $\cdots$ & $\cdots$ & $\cdots$ \\
\hline & Greece Female & $489-2585$ & $\mathbf{x x x x}$ & $\mathbf{x x x x}$ & $\operatorname{xxxx}$ & $\cdots$ & $\cdots$ & $\cdots$ \\
\hline \multirow[t]{8}{*}{ G. intermedia } & \multirow[t]{2}{*}{ Korea Female } & \multirow[t]{2}{*}{$405-2577$} & $\operatorname{xxxx}$ & $x x x x$ & $\mathbf{x x x x}$ & $(\mathrm{xx})$ & $-\ldots$ & $\ldots$ \\
\hline & & & $x x x x$ & $x x x x$ & $\mathbf{x x x x}$ & $(x x)$ & $\cdots$ & $\ldots$ \\
\hline & \multirow{2}{*}{ Japan Male } & \multirow{2}{*}{$442-2578$} & $x x x x$ & $x x x x$ & $\mathrm{xxxx}$ & $(x x)$ & $\cdots$ & $\cdots$ \\
\hline & & & $x x x x$ & $x x x x$ & $\mathrm{xxxx}$ & $(\mathbf{x x})$ & $\ldots$ & $\ldots$ \\
\hline & \multirow[t]{2}{*}{ Japan Male } & \multirow[t]{2}{*}{$483-2581$} & $\mathbf{x x x x}$ & $\mathbf{x x x x}$ & $(x x)$ & $\cdots$ & $\cdots$ & \\
\hline & & & $x x x x$ & $x x x x$ & $(\mathrm{xx})$ & $\cdots$ & $\cdots$ & $\cdots$ \\
\hline & \multirow{2}{*}{ Japan Female } & \multirow{2}{*}{$484-2582$} & $x x x x$ & $x x x x$ & $(\mathrm{xx})$ & $\cdots$ & $\cdots$ & $\cdots$ \\
\hline & & & $x x x x$ & $\mathbf{x x x x}$ & $(\mathrm{xx})$ & $\cdots$ & $\cdots$ & $\cdots \cdot$ \\
\hline \multirow[t]{2}{*}{ G. johnstonii } & \multirow{2}{*}{$\begin{array}{l}\text { Gulf of California } \\
\text { Male }\end{array}$} & \multirow[t]{2}{*}{$531-2587$} & $\mathbf{x x x x}$ & $x x x x$ & $x x x x$ & $\mathbf{x x x x}$ & $(x x)$ & $\cdots$ \\
\hline & & & $x x x x$ & $x x x x$ & $\mathbf{x x x x}$ & $\mathbf{x x x x}$ & $(x x)$ & \\
\hline
\end{tabular}




\section{DISCUSSION}

All strains of Gigartina teedii isolated were dioecious and, in those for which male and female plants were available, a regular cycling of the standard Polysiphonia-type life history occurred. No evidence of spermatangia on female plants was obtained. Female plants have been grown isolated in culture for up to 10 years and have never formed cystocarps unless crossed with male plants. Braga \& Cordeiro-Marino (1985) have, however, observed monoecious plants in Brazilian isolates of $G$. teedii. The life history of G. teedii in culture is quite rapid and a complete cycle is possible in 8-12 months with the faster-growing plants from Italy and Greece showing more rapid cycling.

The morphological differences between strains are very striking. Colour, branch frequency, branching pattern and width of thallus all vary but are fixed in cultured isolates to a surprising degree. It is thus clear that caution should be exercised in ascribing variability in such features to ecological causes too readily, as much of it may be genetic in origin. In culture, plants of Gigartina teedii from the Mediterranean could easily be mistaken for G. johnstonii Dawson from the Gulf of California (West \& Guiry, 1982); there is, however, no genetic link between these entities, as attempted crosses have proved negative (Guiry, 1984). Some strains of G. teedii also resemble G. intermedia Suringar from the Pacific. A female isolate of this species from Korea (kindly provided by J. A. West) formed cystocarp-like protuberances when crossed to male plants of $G$. teedii (Guiry \& West, unpubl.); these protuberances appeared to contain the beginnings of gonimoblast tissue, but carposporangia were not formed. However, three male isolates of G. intermedia from Japan (kindly provided by M. Masuda) do not induce protuberance or cystocarp formation in female plants of $G$. teedii but these plants have not interbred with the Japanese and Korean G. intermedia female plants (Guiry \& Masuda, unpubl.). These data suggest a genetic link between $G$. teedii and some populations of $G$. intermedia, perhaps at the generic level.

The differences in tip elongation rates between $G$. teedii strains are considerable. Strains from the Mediterranean grow $2-3$ times faster at $15^{\circ} \mathrm{C}, 16: \overline{8} \mathrm{~h}$, than Atlantic strains (Table 2) and even among the slower-growing Atlantic strains, the English isolate elongates appreciably faster than the Brazilian isolate. It should be noted that growth optima of non-Mediterranean strains may be at temperatures other than $15^{\circ} \mathrm{C}$. Furthermore, tip elongation may not be an entirely accurate method of assessing overall growth because branching frequency affects the rate of elongation of the main axis. Thus, smaller, more profusely branched plants may have similar biomass production rates to longer, less-branched plants.

Guiry (1984) reported Mendelian inheritance of the olive-green colour mutant of $G$. teedii from Brazil. This colour mutant is recessive and is clearly not sex-linked. The branching patterns of gametangial plants is sex-linked. This would appear to be the first report of sex-linkage of a morphological trait in a red alga (cf. van der Meer, 1986). It seems likely that female plants of $G$. teedii would benefit from having a more profuselybranched thallus in that there would be a greater likelihood of capturing spermatia. This is particularly the case when spermatia are released in long strings of mucilage, as they are in cultured plants of $G$. teedii (Guiry, unpubl.).

The present crossability studies have shown that isolates of $G$. teedii from the north and south Atlantic and those from the Mediterranean are compatible and that their 
progeny are fertile. There were slight differences in the degree of crossability between the two series of crosses carried out, the English strain in particular showing a decided reluctance to cross. This may have been due to a reduction in fecundity as a result of the long time - over 10 years - that the strain has been in laboratory culture. In addition to showing out-cross incompatibility, the strain was often unable to cross with itself. There have been some reports of self-incompatibility in marine red algae in culture, notably in Minium parvum Moe (Moe, 1979) and Gastroclonium subarticulatum (Turner) Kützing (Lee \& West, 1980), but the possibility of this phenomenon occurring in red algae should be treated with caution as cultured plants may develop suboptimal production of male and female reproductive structures after a relatively short time in culture. Previous attempts to cross these Gigartina teedii strains (Guiry, 1984; Guiry \& Maggs, 1985) were successful. It should be noted that if, for example, the Brazilian and English isolates were crossed in isolation, the results would suggest a low level of compatibility, which might give rise to a quite erroneous conclusion. Certainly, the larger the number of strains used in crossability studies, the better.

From the point of view of sexual compatibility, Gigartina teedii is genetically continuous in the Atlantic from $24^{\circ} \mathrm{S}$ (Sāo Paulo, Brazil) to $53^{\circ} \mathrm{N}$ (Galway Bay, Ireland), a distance of some $3200 \mathrm{~km}$. The Mediterranean population appears to be geographically isolated from the Atlantic population, as there would appear to be no populations of $G$. teedii west of southern Italy, but is still sexually compatible with the Atlantic strains. It is possible that $G$. teedii was introduced into the Mediterranean from the Atlantic after the last drying-out of the sea about 5.5 million years ago and, although the eastern and central populations may have been isolated for a considerable part of this period, this has not been long enough for sterility barriers to be built up. Another possibility is that $G$. teedii, an alga with a warm-temperate/tropical distribution, died out in the Mediterranean during the last glaciation ( 20000 years ago) and subsequently returned from a southern refugium. It does seem significant, however, that there are considerable growth rate and morphological differences between Mediterranean and Atlantic populations.

Guiry (1981) reported that female plants of Chondrus crispus Stackhouse from Scotland, England, Ireland, Iceland, Germany and Spain were interfertile with male plants from Nova Scotia. These strains were very variable in shape, branching pattern, thickness and width of thallus, colour and shape of the medullary cells and these differences are maintained in culture. More recent studies have shown (Guiry, unpubl.) that carpospores from such crosses form fully fertile tetrasporophytes and the $F_{1}$ gametophytes are also fully fertile. Chen \& Taylor (1980) have shown, however, that two morphologically-distinguishable strains of this species from Nova Scotia do not cross in culture.

Crossability testing of plants of Gracilaria tikvahiae McLachlan from the Gulf of St. Lawrence in Canada with plants from Florida showed that the two populations were interfertile (van der Meer, 1985) and Guiry \& Freamhainn (1985) showed that isolates of this species from the type locality at Barrachois Harbour, Nova Scotia and those from North Carolina and Texas were also interfertile and that fertile tetrasporophytes were formed from the resultant carpospores. Similarly, isolates of Callithamnion hookeri (Dillwyn) S. F. Gray from disjunct north-eastern Atlantic populations were found to be completely interfertile and formed normal $F_{1}$ gametophytes (Rueness \& Rueness, 1982). Interfertility was also found (Spencer et al., 1981) between four isolates of C. byssoides 
Harvey from Massachusetts, New York, North Carolina and Georgia and with an isolate of $C$. halliae F. S. Collins from Texas. However, none of these strains were interfertile with an isolate of $C$. byssoides from Norway. As the type locality of $C$. byssoides is southwestern England, $C$. halliae is probably a separate entity confined to the eastern Atlantic.

Isolates of Palmaria palmata (L.) Kuntze var. palmata from the eastern and western Atlantic were interfertile; hybridizations between Canadian and Irish isolates yielded robust, healthy tetrasporophytes but the tetraspores from these hybrids were mostly nonviable (van der Meer, 1987). According to van der Meer (1986, 1987), preliminary cytological observations suggest that the hybrid tetrasporophytes are heterozygous for a number of chromosome rearrangements, which may explain meiotic failures. No such tetraspore inviability was observed in hybrids of Gigartina teedii.

These instances of sexual compatibility of populations of marine red algae over long distances in the Atlantic are in contrast to that found in Mastocarpus stellatus (Stackhouse in Withering) Guiry (formerly Gigartina stellata - see Guiry et al., 1984). Guiry \& West (1983) showed that two, and possibly three, breeding groups of genetically-isolated plants with a high degree of geographical separation are found in the eastern Atlantic. Fertilization rarely occurred between plants from these groups and, when it did, few carpospores were viable. Although there are clear morphological differences between plants from each of the breeding populations (Guiry \& West, 1983), it is often very difficult to distinguish them in the wild. Rueness (1978) has pointed out that sexual incompatibility may develop between morphologically indistinguishable populations. In a study of Ceramium strictum Harvey, he found that two morphologically-identical isolates identified as C. strictum from North America and Scandinavia were incompatible. However, C. strictum from Scandinavia was sexually compatible with a strain of $C$. tenuicorne Waern from the Baltic that showed several morphological differences. Rueness (1978) treated $C$. tenuicorne as a subspecies of $C$. strictum. Mathieson et al. (1981) conclude from these data of Rueness that specimens differing markedly in genetically-determined characters may be completely interfertile, and Russell (1986, p. 326), referring to this, remarked "... it is perhaps ... pertinent to ask whether or not the crossings demonstrated in the laboratory ever in practice take place in nature".

Chapman (1978), in reviewing experimental studies on crossability amongst species of Laminariales, rejected entirely the viewpoint that internal reproductive isolation provides the best evidence for the erection of species, and Rice \& Chapman (1985) came to a similar conclusion with regard to the genus Fucus. Chapman (1978) agreed with the view that crossability is not an all-or-nothing criterion and points out that reproductive isolation often corresponds to morphologically well-defined species. Chapman's arguments may hold true for brown algae belonging to the Laminariales and Fucales but are not generally applicable to red algae; a case in point is Ceramium strictum. In Mastocarpus stellatus, entities belonging to the main breeding groups found by Guiry \& West (1983) are recognizable, but not necessarily by even competent field taxonomists. One could question the suitability of describing separate species for these given that the function of taxonomy is not alone to reflect the natural interrelationships of organisms but also to communicate. There is not much point in having well-founded species that only a few can recognize.

Although strains of Gigartina teedii show more or less complete sexual compatibility in culture, morphological differences between them are maintained under uniform 
culture conditions. Preliminary studies indicate that characters like colour, width of thallus, branching pattern and growth rate are heritable but that the inheritance mechanisms are complex. Examination of herbarium material from different geographical locations would lead one to the conclusion that the variation in these characters is phenotypic, but cultured plants show that much of it is likely to be genotypic. Gigartina teedii is a species composed of a number of populations which, although capable of interbreeding, are probably genotypically different from each other. As such it may be said to be composed of a number of ecotypes (Turesson, 1922) or genecodemes (Gilmour \& HeslopHarrison, 1954). It is likely also that many other red algae, particularly those that inhabit the intertidal, have a similarly high level of genetic variation within populations, both on a geographical and a local scale.

The upper temperature tolerance of Gigartina teedii strains is similar (Table 3) and no differences between Atlantic and Mediterranean strains were found. Interestingly, strains of $G$. intermedia from Korea and Japan showed some differences; preliminary crossability studies on these showed that none of these isolates are intercompatible. Male plants of G. johnstonii from the Gulf of California, which are not sexually compatible with G. teedii (Guiry, 1984) or G. intermedia (Guiry \& Masuda, unpubl.), showed a muchelevated upper lethal limit of $33^{\circ} \mathrm{C}$. Gigartina johnstonii is confined to the upper part of the Gulf of California.

Acknowledgements. We are grateful to: the National Board for Science and Technology (Ireland) and the Development Fund, University College, Galway for financial assistance; S. Haritonidis (Aristotle University of Thessaloniki, Greece), M. Masuda (University of Hokkaido at Sapporo, Japan) and J. A. West (University of California at Berkeley, USA) for providing cultures of various Gigartina species; Wendy Guiry and Deirdre Murphy for their able help in the maintenance of cultures; Petra Kadel for her work on the upper lethal limits of Gigartina spp.; P. Cooke who helped with photography.

\section{LITERATURE CITED}

Boudouresque, C.-F. \& Perret, M., 1977. Inventaire de la flore marine de Corse (Méditerranée): Rhodophyceae, Phaeophyceae, Chlorophyceae et Bryopsidophyceae. - Biblthca phycol. 25, 1-171.

Braga, M. R. A. \& Cordeiro-Marino, M., 1985. Reproduction of Gigartina teedii (Roth) Lamouroux (Rhodophyta, Gigartinales) in the field and laboratory. In: Second International Phycological Congress, Copenhagen, 4-10 August, 1985. (Book of abstracts), 19.

Chapman, A. R. O., 1978. Experimental and numerical taxonomy of the Laminariales: a review. In: Modern approaches to the taxonomy of red and brown algae. Ed. by D. E. G. Irvine \& J. H. Price. Acad. Press, London, 423-432.

Chen, L. C.-M. \& Taylor, A. R. A., 1980. Investigations of distinct strains of Chondrus crispus Stackh. II. Culture studies. - Botanica mar. 23, 441-448.

Darwin, C., 1859. The origin of species. Oxford Univ. Press, Oxford, 592 pp.

Feldmann, J., 1941. Lés algues marines de la côte des Albères IV. Rhodophycées (suite). - Revue algol $12,77-100$.

Gallardo, T., Gómez Garreta, A., Ribera, M. A., Alvarez, M. \& Conde, F., 1985. A preliminary checklist of Iberian benthic marine algae. Real Jardin Botánico, Madrid, 83 pp.

Giaccone, G., 1969. Raccolte di fitobenthos sulla banchina continentale Italiana. - G. Bot. ital. 103, 485-514.

Giaccone, G., 1978. Revisione della flora marina del Mare Adriatico (con annotazioni bionomiche e biogeografiche). - Annuar. Parco Marino di Miramare Stazione di Controllo, Trieste, Suppl. 6 (19), 1-118.

Giaccone, G., Colonna, P., Graziano, C., Mannino, A. M., Tornatore, E., Cormaci, M., Furnari, G. \& 
Scammacca, B., 1985. Revisione della flora marina di Sicilia e isole minori. - Boll. Sed. Accad. gioenia Sci. nat. $18,537-781$.

Gilmour, J. S. L. \& Heslop-Harrison, J., 1954. The deme terminology and the units of microevolutionary change. - Genetica 27, 147-161.

Guiry, M. D., 1981. Chondrus crispus Stackhouse "T 4" is a male clone. - Phycologia 20, 438-439.

Guiry, M. D., 1984. Structure, life history and hybridisation of Atlantic Gigartina teedii (Rhodophyta) in culture. - Br. phycol. J. 19, 37-55.

Guiry, M. D. \& Cunningham, E. M., 1984. Photoperiodic and temperature responses in the reproduction of north-eastern Atlantic Gigartina acicularis (Rhodophyta: Gigartinales). - Phycologia 23, 357-367.

Guiry, M. D. \& Freamhainn, M. T., 1985. Biosystematics of Gracilaria foliifera (Gigartinales, Rhodophyta). - Nord. J. Bot. 5, 629-637.

Guiry, M. D. \& Maggs, C. A., 1985. Notes on Irish marine algae - 7 Gigartina teedii (Roth) Lamour. (Rhodophyta). - Ir. Nat. J. 21, 469-508.

Guiry, M. D. \& West, J. A., 1983. Life history and hybridization studies on Gigartina stellata and Petrocelis cruenta in culture. - J. Phycol. 19, 474-494.

Guiry, M. D., West, J. A., Kim, D.-H. \& Masuda, M., 1984. Reinstatement of the genus Mastocarpus Kützing (Rhodophyta). - Taxon 33, 53-63.

Haritonidis, S. \& Tsekos, I., 1975. Marine algae of northern Greece. - Botanica mar. 18, $203-221$.

Kain, J. M., 1987. Seasonal growth and photoinhibition in Plocamium cartilagineum (Rhodophyta) off the Isle of Man. - Phycologia 26, 88-99.

Lee, I. K. \& West, J. A., 1980. A life history of Lomentaria hakodatensis (Rhodophyta, Lomentariaceae) in culture. - Botanica mar. 23, 419-423.

Lüning, K., Guiry, M. D. \& Masuda, M., 1987. Upper temperature tolerance of North Atlantic and North Pacific geographical isolates of Chondrus species (Rhodophyta). - Helgoländer Meeresunters. 41, 297-306.

Mathieson, A. C., Norton, T. A. \& Neushul, M., 1981. The taxonomic implications of genetic and environmentally induced variations in seaweed morphology. - Bot. Rev. 47, 313-347.

Mayr, E., 1942. Systematics and the origin of species. Columbia Univ. Press, New York, 354 pp.

Mayr, E., 1969. Prińciples of systematic zoology. McGraw-Hill, New York, 428 pp.

Mayr, E., 1982. The growth of biological thought. Diversity, evolution and inheritance. Harvard Univ. Press, Cambridge, Mass., 974 pp.

Meer, J. P. van der, 1986. Genetic contributions to research on seaweeds. - Prog. phycol. Res. 4, $1-38$.

Meer, J. P. van der, 1987. Experimental hybridizations of Palmaria palmata (Rhodophyta) from the northeast and northwest Atlantic. - Can. J. Bot. (In press)

Meñez, E. G. \& Mathieson, A. C., 1981. The marine algae of Tunisia. - Smithson. Contr. mar. Sci., 10, 1-59.

Moe, R. L., 1979. Minium parvum gen. et sp. nov., a crustose member of the Rhodymeniales (Rhodophyta). - Phycologia 18, 38-46.

Nizamuddin, M., West, J. A. \& Meñez, E. G., 1979. A list of marine algae from Libya. - Botanica mar. $22,465-476$.

Politis, J., 1936. Sur la flore marine de l' Attique. - Praktika Akad. Athenon 3, 1-44.

Rice, E. L. \& Chapman, A. R. O., 1985. A numerical taxonomic study of Fucus distichus (Phaeophyta). - J. mar. biol. Ass. U.K. 65, 433-459.

Rueness, J., 1978. Hybridization in red algae. In: Modern approaches to the taxonomy of red and brown algae. Ed. by D. E. G. Irvine \& J. H. Price. Acad. Press, London, 247-262.

Rueness, M. \& Rueness, J., 1982. Hybridization and morphogenesis in Callithamnion hookeri (Dillw.) S. F. Gray (Rhodophyceae, Ceramiales) from disjunct north-eastern Atlantic populations. Phycologia 21, 137-144.

Russell, G., 1986. Variation and natural selection in marine macroalgae. - Oceanogr. mar. Biol. 24, 309-377.

Spencer, K. G., Yu, M.-H., West, J. A. \& Glazer, A. N., 1981. Phycoerythrin and interfertility patterns in Callithamnion (Rhodophyta) isolates. - Br. phycol. J. 16, 331-343.

Turesson, G., 1922. The species and the variety as ecological units. - Hereditas 3, 100-113.

West, J. A. \& Guiry, M. D., 1982. A life history study of Gigartina johnstonii (Rhodophyta) from the Gulf of California. - Botanica mar. 25, 205-211. 